\title{
Baba Otoritesinin Yeniden Üretimi
}

\author{
Reproduction of Father's Authority
}

\section{Mehmet Fatih GÜLOĞLU*}

$\ddot{O}_{z:}$ Sosyal bilimler literatüründe günümüz babalarının aile üyeleri üzerindeki otoritesinin gerilediği yaygın bir şekilde iddia edilmektedir. Bu makalede söz konusu iddia radikal şüphe 1şı̆̆ında yeniden tartışılacaktır. Çalışma kapsamında, babaların otoritelerinde yaşanan değişimleri gözlemlemek amacıyla otoritelerinin azaldığı varsayılan bir grup baba belirlenmiştir. Amaçlı örneklem tekniği ile aile eğitimleri kapsamında yürütülen Baba Destek Programı'na (BADEP) katılmış babaların otoritelerinin azaldığı düşünüldüğünden örneklem grubu bu programa katılan babalardan oluşturulmuştur. Temel olarak baba ve otorite kavramlarının karşılıklı dönüşümünün soruşturulacağı bu çalışma şu şekilde tasarlanmıştır: Baba olmak, sınırları kültür tarafından belirlenmiş pratikleri icra etmek üzerine inşa edilmiş bir kavramdır ve babalık aile içinde karşılık bulan bir pozisyonu ifade etmektedir. Otorite ise tüm ilişkilerin kurulabilmesi için kategorik bir ilke olarak tanımlanmaktadır ve bu çalışmada günümüz babalarının otorite üretimine devam ettikleri öne sürülmektedir. Bu çerçevede BADEP'e katılmış 22 baba ile mülakat yapılarak bu iddiaların geçerliliği incelenmiştir. Mülakatlar etnometodoloji ve sembolik etkileşimci yaklaşımın analiz birimi olarak kullanılması yoluyla yorumlanmıştır. Böylece; çalışma babalar için "baba olmak" ve "otorite" kavramlarının anlamını irdelemekte ve otoriteyi yeniden üreten strateji ve teknikleri ortaya çıkarmaktadır. Araştırma sonucunda günümüz babalarının farklı stratejiler -örtük ve açık otorite stratejisi- kullanarak otorite üretimine devam ettikleri belirlenmiş̧ir.

Anahtar sözcükler: Baba Olmak, Baba Destek Programı (BADEP), Otorite, Örtük Otorite Stratejisi, Açık Otorite Stratejisi

\begin{abstract}
In social science literature it is widely claimed that the authority of today's fathers over family members is decreasing. In this article, the pointed claim will be discussed again in the light of radical suspicion. Within the scope of this study, a group of fathers whose authorities were presumed to have decreased, were interviewed in order to observe changes in the fathers' authority. The sample group was formed from parents who participated in the "Baba Destek Programı (BADEP)/ (Father Support Program (FSP)" because it was thought that the authority of the fathers who participated in this program, which is conducted within the scope of the family education through purposive sampling technique, decreased. This work basically investigated the mutual transformation of the concepts of father and authority, was designed as follows: Being a father is a concept built upon exercising the practices whose boundaries are defined by culture, and paternity refers to a position that corresponds within the family. Authority is defined as a categorical principle for the establishment of all relations and in this study it is claimed that fathers today continue to produce authority. In this context, interviews were conducted with 22 fathers who participated in the BADEP and the validity of these claims was examined. Interviews were interpreted through the use of ethnomethodology and the symbolic interaction approach as the unit of analysis. Thus, the study examines the meanings of the concepts of "fatherhood" and "authority" for the father, and it reveals the strategies and techniques that reproduce authoritarianism. As a result of this study, it was determined that today's fathers continue to produce authority employing different, both latent and manifest authority strategies.
\end{abstract}

Keywords: Authority, Being a Father, Father Supporting Program, Latent Authority Strategy, Manifest Authority Strategy

\footnotetext{
* Dr. İstanbul Üniversitesi, Edebiyat Fakültesi, Sosyoloji Bölümü, İstanbul.mguloglu@gmail.com
} 
Aile bütün yönleriyle sosyal bilimlerde geniş bir yer kaplamaktadır. Dünya çapında birçok nedene bağlı olarak aile dinamiklerinin çözülme sürecine girdiği ya da ailenin dağılmaya yüz tuttuğu iddia edilmektedir (Sayın 1990, 78; Thernborn 2004, 129; Gittins, 2011). Aile tarihi üzerine olan çalışmalar, ailenin karşılaştığı değişimleri nedenleriyle birlikte -sanayileşme, kentleşme, bireyselleşmeye vurgunun artması, ekonomik üretim tarzlarındaki çeşitlenme, göç, sınıfsal yapılardaki dönüşüm- açık bir şekilde dile getirmektedir (Poster 1989, 196; Nirun 1994; Goody 2004, 207; Adak 2005, 47). Yaşanan birçok değişim sonucunda aile üyeleri arasındaki ilişkilerinin yürütülmesinde dönüşümler meydana geldiği açıktır. Bu çalışma, dikkatini ailenin hem reisi hem de üyesi olarak babanın karşılaştı̆g 1 dönüşümlere odaklamıştır. Tarihsel olarak ailede babaların egemen olduğu başka bir deyişle babaların aile üyeleri üzerinde birçok tasarrufta bulunma hakkının olduğu ifade edilebilir. Ancak yaşanan değişimler babaların aile üyeleri üzerindeki belirleyici etkisinin ortadan kalktığını öne sürmektedir. Bu söylem, babaların otoritesinin aile üyeleri üzerindeki etkisinin azaldığ maktadır (LaRossa 1988, 451; Thernborn 2004). Bu konuda Sancar (2011, 122) "değişen şey, babanın kendi oğlu üzerindeki hakimiyetinin yok olmasıdır" demektedir. Başka bir deyişle Sancar, Patria Potestas'ın en önemli unsurlarından olan "vitae necisque potestas" in (hayat ve memat hakkının) özellikle ailenin üyesi olan çocuklar üzerinde ortadan kaldığına işaret etmektedir. Kısacası günümüz aile örgütlenmesinde babaların otoritelerinden bahsetmenin neredeyse imkansız olduğu iddia edilmektedir (Sancar 2011, 302). Örneğin Thernborn (2004), aile tarihi üzerine olan çalışmasında günümüz dünyasındaki babalık icralarının tarihsel olarak otoriteden arınma sürecinden geçtiği belirtmiştir. Şüphesiz bu iddiaların aksi yönünde fikirler de bulunmaktadır. Radikal şüphe 1şığında, bu çalışma babalık icralarındaki değişimlerin otoriteden arınmadan ziyade, tarihsel miras ile yeni gelişmelerin birlikte uzlaştırıldığını ve otoriteden arınma söyleminin tarihsel mirasın yadsınmasına yol açtığını öne sürmektedir (Goody 2004, 186). Dolayısıyla aile üyelerinin yaşam dünyalarının biçimlendirilmesinde halen en önemli öğenin baba olduğu gerçeği bu çalışmanın dayandığı ana tezdir. Bir toplumsal pratik olarak babalık icrasında gözlemlenilen değişiklikler bir çözülme ya da arınma değil de toplumsal yeniden üretimin göstergesidir (Bourdieu 2006, 35). Babaların otoritesini, gerileme ya da azalma ekseninden stratejik dönüşümler eksenine taşıma bu çalışmanın amaçlarından biridir. Bu kapsamda öncelikle otorite mefhumu analitik olarak örtük ve açık otorite stratejisi olarak ayrıma tabi tutularak nötrleştirilmiştir. Ayrıca bu analitik ayrımın bütünüyle araçsal olduğu belirtilmiştir. Sonuç olarak da, günümüzde, babaların bir yandan taşıdıkları tarihsel miraslarını yeniden yorumladıkları; diğer yandan da öğrendikleri yeni bilgi ve yöntemlerle tarihsel miraslarını birbirine eklemleyip uzlaştırdıkları ortaya konulmuştur.

\section{Baba Otoritesini Soruşturmak}

Babalık icrası gündelik hayatın içerisinde sergilenmektedir. Gündelik hayat ise bir takım taktik ve stratejilerin sahnelendiği bir zaman-uzam kesişimidir (Giddens 2005, 385). Çalışma babaların otoritelerini yeniden nasıl üretildiğine odaklandığı için babaların gündelik hayatta sergiledikleri otorite üretici strateji ve teknikleri açığa çıkarmıştır. De Certeau'ya $(2008,54)$ göre strateji "bir istek öznesi ile bir erk öznesinin belirli bir çevreyle yalttılmastyla oluşan güç ilişkilerinin ölçülüp tartılması"; taktik ise "ne bir aidiyet üzerinden, ne de ötekinin, görünür bir bütünlük olarak ayırt edilmesini sağlayan bir sınır üzerinden yapılan hesaplama"dır. Aile kurumunun temsilcisi olarak babaların otoritelerini yeniden üretmek için kullandıkları genel tarzlar stratejidir. Taktik ise babaların babalıklarını icra ederken otoritelerini yeniden üretmek için kullandıkları yol ve yöntemlerdir. Kurumsal anlamda ailenin reisi olan baba stratejiler kullanırken; ailenin bir üyesi olan baba taktikler kullanmaktadır. Gündelik hayatı hareketli kılan 
taktik ve stratejiler bir uzamda gerçekleşir. Taktik ve stratejilerin üzerinde uygulandığı zeminin kurucusunun ve kategorik ilkesinin otorite olduğu bu çalışmanın ana varsayımıdır.

Gündelik hayat içerisinde babaların otorite ile olan ilişkisini soruşturmak için öncelikle varsayımsal olarak otoritelerinin gerilediği düşünülen karş1-olgusal bir tipoloji geliştirmek zorunludur. Çalışma, Baba Destek Programı'na katılmış babaların aile üyeleri üzerinde herhangi bir otoritelerinin olmadığını varsaymaktadır. Bu bağlamda çalışmada şu sorulara cevap aranmıştır: Babalar için otorite nasıl bir anlam taşımaktadır? BADEP eğitimine katılmış babalar aile üyeleri üzerindeki otoritelerini nasıl ve hangi araçlarla yeniden üretmektedirler? $\mathrm{Bu}$ sorulara cevap verebilmek için BADEP eğitimine katılmış 22 baba ile görüşmeler yapılmıştır. Nitel desende tasarlanan çalışmada yarı yapılandırılmış görüşme formu ile derinlemesine mülakatlar yapılmıştır. Örneklem seçimi ise nitel çalışmaya uygun bir şekilde amaçlı örnekleme tekniği ile belirlenmiştir. Mülakatlar ses kaydı alınarak gerçekleştirilmiştir. Görüşmelerin deşifresiyle elde edilen metin kodlanmıştır. Ardından kodlamalar çeşitli başlıklar altında tasnif edilerek temalar oluşturulmuştur (Glesne 2012, 251). Kısacası tematik bir analiz yapılarak yorumlara ulaşılmıştır. Elde edilen temalar sonucunda araştırma bir yandan babaların otoriteye dönük anlam dünyalarını analiz etmek için sembolik etkileşim yaklaşımını; diğer yandan da babaların ailelerinde otoritelerini üretmek için kullandıkları strateji ve tekniklerin neler olduğunu ortaya koymak için etnometodolojik yaklaşımı analizi birimi olarak kullanmıştır.

\section{Aileleri Denetlenebilir Kılma Girişimi: Aile Eğitimi}

Aile eğitimleri bir bütün olarak ailenin karşılaştığı sorunların yine aile üyeleri üzerinde yaratabilecekleri olası tahribatları en aza indirebilmek için uzun bir süredir dünya çapında uygulanmaktadır. Bu çerçevede aile eğitim programlarının genel amaçları şunlardır:

"Aile eğitimi, ailelerin çocuklarını sağlıklı bir biçimde yetiştirebilmeleri için gelişstirilmiş, organize edilmiş etkinliklerin tümünü kapsar. Aile eğitim programlarının hedefleri anne babanın, çocuğun doğum öncesi ve sonrasi gelişimi konusunda bilgilenmelerini; gelişim ödevlerinin farkina varmak; çocuğun her alanda gelişimini desteklemek; çocuklar ile iletişim kurmaları konusunda bilgilendirmek; davranış değiştirebilmenin kurallarını ögretmek; çocuk sağlığı konusunda bilgilendirmektir" (Üstünoğlu 1991, 83).

Aile eğitimleri çocuğun sağlığının korunmasına, bakımına ve gelişimine yardımcı olmak, onları desteklemek, onlar ile iletişim kurabilmek, çağa uygun nesil yetiştirmek, aile üyeleri arasındaki bağı kuvvetlendirmek gibi birçok amaç etrafında tasarlanmıştır. Program, nesiller arası iletişim kopukluğundan ve bilgi aktarımından doğan boşluğu doldurma gayretindedir (Şen \& Demirkan 2008, 116). Bu programların ortaya çıkış koşullarının arka planında iki temel dinamik yatmaktadır. İlki bilimsel düşünce ışığında çocuk yetiştirme becerilerinin anne ve babalara kazandırılması; ikincisi de uzmanlaşma sürecinin aile üyeleri üzerindeki baskının artmasıdır. Bu bağlamda Avrupa ve Amerika'da 1960'larda aile eğitim programları uygulanmıştır. 1970'lerde uzman sayısının da artmasıyla beraber anne-babalar, çocukları için en doğrusunu uzmanların bildiğine inanmaya başlayıp destek hizmeti almaya yönelmişlerdir (Keyif 2008, 9).

Ülkemizde aile eğitimlerinin uygulanmaya başlaması Avrupa ve Amerika’ya göre daha geç tarihlidir. Çünkü ülkemizde nispeten 'güçlü baba' figüründe devamlılığın olduğu öne sürülebilir. Yine de, ülkemizde yaşanan göçler ve bunun sonucunda ortaya çıkan eğitimde firsat eşitliğinden yoksunluk aile eğitimlerin ortaya çıkması için gerekli koşulları üretmiştir. Göç sonucu çocukların korunması ve kollanması için anne-babanın eksiklikleri eğitim aracılığıyla gideril- 
mek istenmiştir. Ayrıca bu ailelerin çağdaş yaşam koşullarına uyum sağlaması böylece kaliteli insan sermayesinin yeniden üretimi hedeflenmiştir. Bu amaçlar etrafında ülkemizde sistemli aile eğitimi ilk olarak 1982 y1lında İstanbul Üniversitesi Edebiyat Fakültesi Eğitim Bilimleri Bölümü bünyesinde tasarlanıp uygulanmıştır. 'Ana-Baba Okulu' projesi, 1989 yılından itibaren ise yaygınlaştırılmıştır (Şen \& Demirkan 2008, 119). Bu program ile aile içi iletişim, çocuk bakımı gibi birçok konuda annelere uzun süreli bir eğitim verilmiştir (Malkoç 1991, 21). Bu programa ek olarak Millî Eğitim Bakanlığı bünyesinde Aile Eğitim Programı (AEP) 1993 yılından beri uygulanmaktadır. 1993-2015 yılları arasında ise 43839 kurs ile 2001922 kişiye ulaşılmıştır (MEB 2015). Sadece 2010-2015 y1lları arasında 24330 kurs ile toplamda 469079 kişiye eğitim verilmiştir (MEB, Strateji Geliştirme Başkanlığı, 2016). Aile eğitimleri genel olarak ülkemizde annelere dönük bir uygulamadır. Ancak Anne-Çocuk Vakfi (AÇEV) 1996 yılında annelere verilen eğitimin eksikliklerinden hareketle programın babalara da uygulanması için bir program geliştirmiştir. Bu program ile babaların eğitilerek aile üyeleri ile olan ilişkisi daha bilimsel ve demokratik bir çizgiye çekilmek istenmiştir. Bu çalışmada BADEP programı otorite kavramının dönüşümünü anlamak için bir araç olarak ele alınmış olup, bu program sonucunda babaların otoritelerinin ortadan kalktığı varsayılmıştır. Aşağıda bu programın amaçları ve babaların otoritelerini dönüştürmelerine etkileri belirtilmiştir.

\subsection{Baba Destek Programı (BADEP)}

BADEP katılımcısı babaların aile üyeleri üzerinde otorite tesis etmekten kaçınmaları programın hedef çıktıları arasında yer almaktadır. Babalık icralarının yeniden biçimlendirilmesine dönük bilimsel ve entelektüel bir çabanın ürünü olan BADEP, babalık icralarının toplumsal olarak kabul edilebilir bir seviyede gerçekleştirilmesi için babaların eğitilmesine odaklanmıştır. $\mathrm{Bu}$ sayede 'sağlıklı' bir aile ortamının tesis edilmesi; aile üyeleri üzerinde herhangi kalıcı bir hasara yol açmadan karşılıklı iletişimlerin kurulması; aile üyelerinin özgür bir şekilde yetiştirilmesi ve babaların demokrat baba tipini benimsemeleri gibi hedeflere ulaşmak için çabalanmıştır. Başka bir deyişle program, baba otoritesinin aile üyeleri üzerindeki baskı kurucu yönünü azaltma ve aile üyelerini özgürleştirme yönünde bir amaca sahiptir. Eğitim sonucunda babaların aile üyeleri üzerinde olduğu düşünülen tahakkümden uzaklaşacakları düşünülmektedir. Ancak bu düşünce, babaları 'edilgen' olarak tasarlamak ve onları 'cahil, hiçbir şey bilmez bir tip' olarak düşünmek anlamına gelir. Oysa herhangi bir özne gibi babalar da düşünerek, tasarlayarak ve belirli amaçlar doğrultusunda aile üyeleri ile ilişki kurmaktadırlar. Başka bir deyişle babalar yeniden anlamlandırma süreçlerini tecrübe etmektedirler (Butler 2008, 60). Bu nedenle BADEP babalık icrasında yeni sorunların doğmasına yol açmaktadır. BADEP, aile üyeleri arasındaki ilişkileri demokratikleştirerek aile üyeleri arasındaki ilişkiyi babalarının tekelinden çıkarmayı ve aile üyeleri arasındaki ilişkileri eşitler arası bir ilişki biçimine dönüştürmeyi amaçlamaktadır. Ancak BADEP, babaların otoritelerinin gerilediği iddia edilen günümüz modern dünyasında babaların otoritelerinin yeniden üretilmesine katkı sunmaktadır. Çünkü babalara aile üyeleri ile kurulacak ilişkide nasıl davranmaları hakkında detaylı teknik beceriler kazandırılmaktadır. Başka bir deyişle aile üyeleri arasındaki ilişkinin 'hijyenikleştirilmesi' olarak BADEP, babalara otoritelerini üretmeleri için yeni imkânlar sunmaktadır.

Ülkemizde babalık icralarının yürütülmesi için gerekli bilgi ve deneyim aktarımında -Avrupa ve Amerika ile kıyaslandığında- nispi bir süreklilik olmasına rağmen yakın dönemdeki hızlı dönüşümler kuşaklararası bilgi ve tecrübe aktarımında sorunlara yol açmıştır (Kılıç 2010, 101). BADEP bu sorunlarla başa çıkmak üretilmiştir. AÇEV tarafından geliştirilen BADEP, ilk olarak pilot uygulaması 1996 yılında yapılmış olup, 1999 yılından itibaren yaygın uygulamaya geçilmiştir (Koçak 2004, 15). Ülke çapında yaygınlaşması ise 2004 yılında MEB'in Hayat Boyu 
Öğrenme Genel Müdürlüğü ile AÇEV arasında imzalanan protokol neticesinde gerçekleşmiştir. 1996 y1lından bugüne AÇEV verilerine göre açılan 1864 BADEP kurs programına toplamda 46376 baba katılmıştır (AÇEV 2016). MEB verilerine göre ise sadece 2010-2015 arasında toplamda 1450 kurs açılmış olup, 25883 baba eğitilmiştir (MEB 2016). BADEP babaların, çocuk gelişimi hakkında bilgisini arttıran, onlarla iletişim kurma becerileri edindiren ve sonuç olarak da demokratik tutumu kazandıran bir yaygın eğitimdir (Kılıç 2010, 105). BADEP'in hedef kitlesi alt-sosyo-ekonomik gelir grubundan babalar olarak belirlenmişse de (Koçak 2004, 14); bugünkü hedefi tüm ülke çapında babaların aile üyeleriyle olan ilişkilerini ve iletişimlerini olabildiğince sağlıklı (anlamı müphemdir) bir seviyeye çekmektir. Genel olarak ise BADEP'in amaçları şunlardır:

\begin{abstract}
"Babanın çocuk gelişimdeki kendi öneminin farkına varması; babanın çocuk gelişimi konusunda bilgi edinmesi; babanın edindiği bilgiler ışı̆̆ında çocuğun gelişimine uygun beklentiler içine girmesi; çocuk istismarının önlenmesi; babanın, çocuk gelişiminde daha etkili bir rol oynayabilmesi için gerekli desteği almasi; babanın da çocuk yetiştirmeye dâhil edilmesiyle cinsler arası bir denge sağlanmasi; babanın demokratik yöntemler hakkında bilgi edinip bunları evde, eşi ve çocuklartyla yaşama geçirmesi, böylece daha demokratik, daha mutlu bir aile ve toplum yapısının desteklenmesi; babanın programda öğrendiği bazı becerileri (iletişim becerileri, problem çözme stratejileri, vs.) başka ilişkilerinde de kullanması" (Koçak 2004, 15).
\end{abstract}

Program gelişim psikolojisinin verilerini dikkate almakta ve ailelerde demokrat baba tipinin geliştirilmesine özel bir önem vermektedir. Örneklemi oluşturan babaların bu amaçları bütünüyle içselleştirdikleri eğiticilerin görüşlerine dayanılarak kabul edilmiştir. Dolayısıyla örneklemi oluşturan babaların otoritenin baskı kurma, tahakkümde bulunma, ayrıcalıklı olma, emir verme gibi anlamlardan uzaklaştıkları varsayımsal olarak kabul edilmiştir. Bu çerçevede BADEP'e katılmış babaların babalığa bakışları ve otoriteden anladıkları ortaya konulmuştur.

\title{
3. Baba Olmak ve Otorite
}

Örneklemi oluşturan BADEP eğitimine katılmış ve eğitimin çıktılarını kendi hayatlarında deneyimlemiş babalar için baba olmanın ve otorite kavramının anlamı soruşturulmuştur. Buna ek olarak babaların aile üyeleri üzerinde otorite üretmek için hangi yol ve yöntemleri kullandıkları da ifade edilmişsir.

\subsection{Yeniden Üretilen Babalığın Anlamları}

Ülkemiz özelinde babalar, genel olarak, erkeklik, toplumsal cinsiyet ve çocuk psikolojisi/ gelişimi üzerindeki olumsuz etkisi bağlamında gündeme getirilmektedir. Oysa aile sosyoloji açısından ve tarihsel olarak babalar hem aile kurumunun reisi hem de bu kurumun bir üyesi olarak önemli bir pozisyonu işgal etmektedirler. Bu çerçevede babaların aile sosyolojisi ve toplumsal ilişkilerin yeniden üretilmesindeki önemi bağlamında ele alınması önem arz etmektedir. Bu çalışmanın radikal şüpheyle sormuş olduğu soru kapsamında, bir otoritesinin kalmadığ 1 iddia edilen babalar hakkında toplanan veriler analiz edilmiştir. Bu analizler çerçevesinde ilk olarak baba olmanın bir süreç olduğu ve bir erkeğin baba olmayı zamanla öğrendiği görülmüştür. İlk olarak erkek için şaşkınlık dışında bir anlam ifade etmese de, MY'nin de vurguladığı gibi belirsizlikle karşılaşma anlamına gelmektedir. MY bu ilk etkinin geçmesiyle baba olmanın çocuk hakkında endişe duymaya dönüştüğünü belirtmiştir. 
"Baba olmak müthiş bir duygu. Illk baba olduğumda kafandan aşağıya kaynar su dökülmüş oluyor gibi. Bundan sonra ne olacak? Bilmiyorsun. $O$ çocuğun sorumluluğunu. (...) Yani bu işin çocuğu büyütmesi var. Koruması var. Yetiştirmesi var. Kademe kademe bu büyüdükçe okulu var" (MY, 40 yaşında, kuyumcu, İstanbul).

Baba olmanın tanımı literatürde iki farklı şekilde yapılmaktadır. Başka bir deyişle babanın ne olduğu hakkında, literatürün ittifak ettiği biyolojik ve kültürel olmak üzere ikili bir tanım mevcuttur. İlk anlamda baba, "çocuğun dünyaya gelmesinde etken olan erkek, çocuğu olmuş erkek, peder" demektir (Türkçe Sözlük 2009, 171; Zeybekoğlu 2013, 301; Online Etymology Dictionary, 2016). Bu tanım tarihsiz ve kültür-dışı olup babaların niteliklerini ya da babalık pratiklerini nasıl icra ettikleri hakkında herhangi bir fikir vermediği gibi sadece babanın nedenselliğine vurgu yapmaktadır. Yine de baba olmak biyolojik bir bağı içermekte, bir çocuğu gerekli kılmaktadır. Nitekim babalar ile yapılan mülakatlar babaların biyolojik bağı önemsemekle birlikte asıl önemli olanın 'babalığın icrası' olduğunu dile getirmektedirler. Başka bir deyişle baba olmayı sadece biyolojik bir nitelik olarak görmemektedirler. Bu konuda SG baba olmay1 ata olmak şeklinde tanımlamıştır. Nitekim SG biyolojik olarak her erkeğin baba olabileceğini ancak her erkeğin babalık yapamayacağını; SA baba olmanın sadece biyoloji ile yürütülemeyeceğini ve İF baba olmanın fiziksel olarak başladığını ancak çocuğa aktarılanlar ile belirlendiğini belirtmiştir.
"Ben babalık ve baba olmayl şöyle ayırıyorum. Babalık ve atalık. Herkes baba olabiliyor. Diyelim bir kadınla akşam beş dakikalık bir münasebet sonucunda tesadüfen baba olursunuz. Ama atalı bence bizim toplumu- muzda birçok insanların beceremediği, babalık ve atalık. Atalı da şey- dir. Dünyaya getirdiğin çocuğun, dünyaya getirirken acaba ben bunun isteklerini karşılayabilir miyim?” (SG, 38 yaşında, Öğretmen, Eskişehir).
"Demin bahsettiğim şeyi doğallı̆̆ simgeliyor. Baba olursan doğalsın. Babalık yaparsan bazı şeyleri uydurursun" (SA,41 yaşında, Öğretmen, Eskişehir).
"Her insan baba olabilir. Fizikseldir. Baba olduktan sonra baba olmanın sizin üzerine yüklediği o şeyi yapmanız lazım yani. Isşte aile maddi olarak bir aileye bakmak, manevi olarak onlara gerekli desteği săglamak. Ora- da devreye babalık giriyor. Baba olabilirsiniz, anne de olabilirsiniz. Işs babalık ya da anneliğe geldiğinde orada olay tamamen sizin karşı tarafa ne verdiğinizle alakal bir şeye geliyor. Maddi olarak manevi olarak" (İF, 40 yaşında, Banka Müdürü, İstanbul).

Mülakatların gösterdiği gibi, baba olmak, biyolojik nedensellik ile yürütülebilecek bir şey değildir. Bu bağamda literatürün de gösterdiği gibi baba olmanın kültürel anlamı öne çıkmaktadır. İkinci anlamda baba olmak ise, kültürel bir yaşamın gereklerini yerine getirmektir. Baba olmak biyolojinin ötesinde ve birtakım toplumsal kategoriler ekseninde tanımlı olan pratiklerin çocuğu olan erkekler tarafından icra edilmesidir. "Başlangıcı biyolojik bir nitelik taşıyan çocukluk, annelik ve babalık olguları kendilerini çevreleyen yoğun bir kültürel, tarihsel ve toplumsal bağlamın içinde değerlendirilmekte ve anlamlandırllmaktadır. Hem çocuk hem de anne-baba böyle bir bağlamın içinde toplumsallaşmaktadır" (Zeybekoğlu 2013, 300). Babalar, çekip çevirme işini yaparak dış dünya yani kamusal ile iç dünya yani özel arasındaki köprü görevini icra etmektedirler (Öztürk 2012, 77). Kültürel olarak ifade edilen baba olmak durumu, birçok 
sorumluluk ve tarihsel anlamlarla yüklüdür (Smelser 2001, 5418). Örneğin, HKA için baba olmak evin direği, İF için ailenin çınarı ve aile üyelerini sosyalleştiren kişidir. ÖY için ise hem çocuğun gelişimine destek olmak hem de onu sosyalleştirmeyi başarmak demektir. Dolayısıyla kültürel tanım babanın sorumlulukları ekseninde bir anlam bulmaktadır.

"Baba olmak aslinda genelde hep anneyi derler ama baba olmak gerçekten bu evin direği. Gerçekten kilit nokta yani baba. (...) Çocuğun sosyal hayata karışması bunu bu şekilde yapması için en azından ben onunla gezmek zorundayım. (...) Baba olmanın bir gerçekten rol yani. Baba çocuğun gözünde bir rol. Ha klz çocuğu da olsa erkek çocuğu da olsa gerçekten baba bir rol model oynuyor yani" (HKA, 36 yaşında, Memur, Eskişehir).

"Hani hep babayı şey diye tanımlarlar ya baba öldükten sonra dinliyoruz baba öldükten sonra baba bir ă̆aç, hani onun gölgesi bile yetiyor. Hani bir çınar" (İF, 40 yaşında, Banka Müdürü, İstanbul).

"Onu dünyaya getirmek kolay da onu büyütmek, hani bunun inanç tarafi da var, bunun sosyal sorumluluğu da var. (...) Onu koruyup, kollamak canlanıyor. Onun maddi manevi ihtiyaçlarını yanında bulunmak" (ÖY, 41 yaşında, Mühendis, Eskişehir).

Erkek kişi, velayetine aldığı bir çocuk sayesinde içinde bulunduğu kültürel atmosferde baba olmayı deneyimler. "Ana babalık bir taraftan kültür ürünüdür, diğer taraftan da kültürü oluşturur; bu nedenle de, insan-kültür ilişkisinin en temel aracısıdır" (Kağıtçıbaşı, 2012: 61). Nitekim MB için baba olmak, babanın çocuk ile terbiye edilmesi anlamına gelmektedir. Dolayısıyla bir erkek her ne kadar kendi çocuğunu biçimlendiriyor olsa da çocuk tarafından kendisi de yeniden biçimlenmektedir. Aynı şekilde ED için baba olmak yeniden doğmaktır. Baba, çocuğu vasitasıyla toplumsal ve kültürel olarak yeni bir nitelik edinmektedir.

"Belki daha sonradan duygusallığı yakalamaya başlıyorsunuz. Farkına vardıkça böle, kucağınıza aldıkça, onu öpüp okşadıkça, kokladıkça böyle. Yavaş yavaş baba olduğunuzu hissetmeye başllyorsunuz. Baba olmak bir süreçtir. (...) Kendinizi bir şekilde terbiye ediyorsunuz. Kendiniz de aslında zaman içinde bir şekilde eğitiyorsunuz" (MB, 41 yaşında, Binbaşı, İstanbul).

"Baba olmak baba olduğumda hayatın benim için yeniden başladı̆̆ını hissettim (...) Baba olmak dünyaya yeniden gelmek gibi bir şey oldu. İkinci kez dünyaya gelmek gibi bir şey oldu benim için. (...) Baba olmak, üzerinde kanatlarınla gölge yaptı̆̆ın, nasıl diyeyim koruyucu bir -çok melek metaforuyla falan açıklamak istemiyorum da- koruyucu bir kalkan olarak üzerinde uçmak gibi” (ED, 33 yaşında, Öğretmen, Eskişehir).

Baba olmak, aynı zamanda kültürün erkek üzerinde kurmuş olduğu tahakküme işaret etmektedir. Çünkü baba olmanın kültürde belirli kalıpları söz konusudur ve baba olmak bu kültürel kalıpları icra etmeyi gerektirir. Dolayısıyla kültür, hem babalığı üretmekte hem de babaların icralarıyla yeniden üretilmektedir. Babaların, baba olmayı deneyimlediği anlarda "nasıl baba olunur?"un bilgisi çevredeki diğer babalar ve ideolojiler aracılığıla baba adayına aktarılmaktadır. Bu asli sosyalizasyondur (Berger \& Luckmann 2008). Böylelikle babalar, beklenilen ve istenilen şekilde baba olmayı deneyimlerler. 
Babalık, çocuk tarafından şekillendirilen toplumsal bir pozisyondur. Aynı şekilde çocuk da baba gibi kültürel bir üründür. "Çocukluk, salt biyolojik bir kategori değil, aynı zamanda toplumsal ve siyasal bir tahayyüldür; tarihsel serüveni boyunca ekonomik, sosyo-kültürel ve politik düzlemde farklı şekillerde algılanmış ve kavramsallaştırılmıştır" (Öztan 2013, 3). Bu anlamda babalık değişen çocukluk paradigmasıyla birlikte yapılaşır. Nitekim genel olarak EE için baba olmak, aile içinde önemli bir pozisyona sahip olmak demektir.

"Güler yüz, sevgi, saygl, güven yani anlayış bunların hepsi babalı̆̆ın rollerini değiştiriyor. Babalı̆̆ın pozisyonlarını değiştiriyor" (EE, 40 yaşında, Vestel bayisi, İstanbul).

Özellikle çocuğun gelişim dönemlerinde babalık pratiklerinin öneminin uzmanlar tarafından aşırı vurgulanması babalığın denetim altına alınmasına yol açmıştır. Babalık icrasının biçimlendirilmesinde psikanalitik bakışın da büyük bir etkisi söz konusudur. Babanın varlığının çocuk üzerinde travmatik etkiler yaratabileceği düşüncesi babanın tahakküm altına alınması sürecini üretmektedir. Psikanalizin babalara bakışı neticesinde modern dünyada aile, çocukların her tür sağlı̆̆ından sorumlu birincil merci haline gelmiştir (Furedi 2013). Babaların çocuğun gelişimi için hayatiyetinin vurgulanmasındaki artış aynı zamanda profesyoneller tarafından babaların pozisyonuna bir müdahaledir.

Baba olmanın bu anlamlarının yanı sıra asıl olarak sorumluluk kavramı ile birlikte günümüz babalığı değerlendirilmektedir. Babanın sorumluluklarının başında, "çocuğunun ve -çoğu zaman- çocuğunun annesinin geçimini sağlamak" gelmektedir (Zeybekoğlu 2013, 306). Ayrıca tarihsel olarak bakıldığında babanın sorumlulukları oldukça fazladır. Üstelik yaşanan değişim karşısında babaların sorumlulukları daha da karmaşık bir hal almıştır. Babaların tarihsel sorumlukları şunlardır:

"Ailenin mal varlı̆̆ını bir bütün halinde tutmak; Mümkün olduğu kadar aile fertlerinin tarlalar üzerinde ortaklaşa emek harcamasını sağlamak; Geniş aile fertlerini bir çatı altında barındırmak; Kazan kaynatıp karınlarını doyurmak, giydirmek; Aile bireylerinin 'ögretim sürecine’ katılımlarını örgütlemek; Ailenin gelirlerini bir kesede toplayarak bu gelirler üzerinde tasarruf etmek; Başlık parasını ödemek ve oğlun düğününü yapmak" (Akın 1991, 150).

Mülakatlar, BADEP'e katılmış babaların bu sorumluluklarla da yüklü olduklarını göstermektedir. TK için baba olmak ailenin merkezinde olmak, sorumluluk altına girme, iletişim uzmanı olma, sağlıklı bir iletişim kurabilme demektir. İI için de aynı şekilde baba olmak ailenin bütünleştiricisi, aile üyelerinin her şeyinden sorumlu bekçisi, aile üyeleriyle ilgilenen, evin ve aile üyelerinin ihtiyaçlarını karşılayan, aile üyelerini güven için içinde tutan kişidir.

"Baba olmak merkez noktada olduğumu düşünüyorum. Onlar için merkezdeyim ben. Bana göre ise baba sonuçta külfete katlanan ve onlar için çabalayan kişi olarak görüyorum" (TK, 43 yaşında, Avukat, İstanbul).

"Ailenin en tepesine düşer. Baba muhtemelen en tepeye. Ya baba işte bence hani şeyin ailenin direği. (...) Beyni yani. Ya her şeyi. Ailenin her şeyi. (...) Temelden çatıya kadar baba olmazsa ne temel oluyor ne çatı oluyor ne bina oluyor. (...) Benim gözümde ailenin işte sorumlusu yani. O çocuğunu aileni düşünmen gerekiyor. Eşini düşünmen gerekiyor. Her şey senin omuzların üstünde. O evin geçimi. O da var. Yaşıyoruz. Yaşa- 
mak için de paraya ihtiyacımız var. O parayı da bir şekilde babanın kazanması lazım. Bu sorumluluk sana ait" (İ̈, 37 yaşında, Balıkçı, İstanbul).

SG için de baba olmak, ata olarak aile üyeleri için çabalamak, onların isteklerini karşılamak, yaşam koşullarını iyileştirmek, sorumluluklarını üstlenmek demektir. HK, MT ve ÖY için baba olmak sorumluluk yüklenmektir.

"Atalık da şeydir. Dünyaya getirdiğin çocuğun, dünyaya getirirken acaba ben bunun isteklerini karşılayabilir miyim? Ben bunun yaşamını idame ettirebilmesi için gerekli şartlar oluşturabilir miyim? Ya da ben bir çocuğun sorumluluğunu almaya hazır mıyım? Sorularına cevap alabiliyorsan, istek ve ihtiyaçlarını karşılamaya, o sorumluluklarını almaya, almaya değil alabiliyorsanız ata olabiliyorsunuz" (SG, 38 yaşında, Öğretmen, Eskişehir).

"Çocuk çok büyük bir sorumluluk. Bu sorumluluğun üstlenilebilmesi için insanların bazı vasıflara sahip olması lazım" (HK, 45 yaşında, Okul Müdürü, İstanbul).

"Baba olmak tabi de sorumluluk. Yani doğru yerde doğru kararlar verince daha mutlu oluyorsunuz. Eğitimleriyle ilgili, onların istekleriyle ilgili" (MT, 43 yaşında, Oto Malzeme Bayisi, Ankara).

"In ya çocuk sorumluluğu almak. Onu dünyaya getirmek kolay da onu büyütmek, hani bunun inanç tarafi da var, bunun sosyal sorumluluğu da var" (ÖY, 41 yaşında, Mühendis, Eskişehir).

BADEP'e katılmış babalar için baba olmak süreç içerisinde öğrenilen pratikler setini icra etmek anlamına gelmektedir. Başlangıçta bir belirsizlik ve şaşkınlık durumu olarak betimledikleri baba olma durumu, zamanla biyolojik bağın ötesinde birçok sorumluluğun yerine getirilmesine dönüşmektedir. Bunun yanı sıra her ne kadar BADEP daha demokratik bir baba figürünü katılımcılarına aşılasa da klasik anlamıyla baba ve çınar imgesi halen sürdürülmektedir. $\mathrm{Bu}$ çerçevede BADEP'e katılmış babalar için baba olmak geleneksel olarak taşınan miras ile yeni yol ve tekniklerin kullanımıyla mevcut gelişmeleri harmanlama becerisini içermektedir. Bu bakış açısından hareketle günümüz ailelerinde baba olmak bir erkeğin biyolojik ya da kurumsal olarak edindiği çocuğuna yönelik kültürce sınırları çizili babalık pratiklerini yerine getirmesiyle kazandi $\breve{g}$ yeni toplumsal pozisyon şeklinde tanımlanabilir. Kültürel pratiklerin icracısı olarak babaların ailelerindeki pozisyonları onların otorite kavramıla olan ilişkilerini biçimlendirmektedir. Bir sonraki kısımda BADEP'e katılmış babaların otoriteden nasıl bir şey anladıkları ve aile üyeleri üzerindeki otoritelerini nasıl icra ettikleri gösterilmiştir.

\subsection{Otorite Kavramını Zenginleştirmek: BADEP'li Babaların Otorite Anlayışları}

Grekçe 'augeō' sözcüğünden gelen otorite arttırmak demektir. Latince 'auctoritas' olarak ifade edilmiş olup 'sahip olma hakkı, kararlılık gösterme, etki edebilme' anlamlarına gelmektedir (Kardeş 2015, 41). Otoritenin Arapça karşılığ1 'salahiyet' olup, yeterlik, uygunluk manalarını içerir. 'Auctoritas' Roma Hukukunda bir başka insanın eylemini oluşturma yetkisi anlamında da kullanılır (Supiot 2014, 171). Türkçe karş1lığ1 ise yetkidir. Türkçe Sözlük $(2009,1520)$ ise otoriteyi şu şekilde tanımlamıştır: "Yaptırma, yasak etme, emretme, itaat ettirme hakkl veya gücü, yetke, sulta, velayet; siyasi veya idari güç; çalışmalarıyla kendini kabul ettirmiş, başarılı kimse". Otorite genel olarak güç, nüfuz ve liderlik ile birlikte anılarak yaşamın birçok alanında 
işlerliğe sahiptir. Ayrıca otoritenin ayrıcalıklı olma ve yetkili kılma anlamları bulunmaktadır (Hançerlioğlu 2007, 448; Cevizci 2011, 332). Bu iki anlam günümüz modern dünyasında otoritenin yadsınmasına yol açmaktadır. Otoritenin ayrıcalıklı olma ve yetkili kılma anlamı kavramın güçle ittifak kurmasına yol açarak otoriterliği üretmektedir. Herhangi birine otoriteden ne anladıkları sorulduğunda verilen ilk anlamın otoriterlik olduğu kolaylıkla deneyimlenebilir. Her ne kadar otorite emir verme hakkl anlamını içerse de insanlığın üretim ve yeniden üretim faaliyetlerinin temelini oluşturur (Sills 1968, 473-474). Bunların yanı sıra "Webster's Ninth Collegiate Dictionary'de (1983) otorite, 'düşünce, fikir ve davranışı yönlendirme ya da etkileme gücü" olarak tanımlanır (Smelser \& Baltes 2001, 973). Davranışı belirleme gücü politik bir anlam taşımakla birlikte gizil olarak karşılıklı tarafların varlığını ima eder: Gücü elinde bulunduranlar ve güce maruz kalanlar. Bu ikili ayrım karşılıklı ilişkiyi esas alır. Bu çerçevede otoritenin başka bir anlamı da ilişkisellik olarak ortaya çıkar. Otorite, "bireyler arasında var olan bir ilişki"dir (Smelser \& Baltes 2001, 978). Aynı şekilde Kojêve $(2007,14)$ için de "otorite zorunlu olarak bir ilişki"dir. Bir ilişki olarak otorite taraflar arasında etkileşimi şart koşar. Bu çalışmada kavram, nötrleştirilerek otoritenin kültür üretici vasfı yeniden gün yüzüne çıkarılmış ve babaların otoritelerinin yadsınmasının önüne geçilmiştir. Tespit edilen bu anlamlarından hareketle otorite her tür ilişkinin kurulduğu zemin ya da ilişkilerin kurulabilmesinin kategorik ilkesidir. Otorite tüm karşılaşma, buluşma, görüşme ve çatışmaların üzerinde kurulduğu zemindir. Yukarıda ifade edilen tanımlar ışığında otorite kavramının bir yanıyla arttırma ve ilişkisellik anlamını; diğer yanıyla da yetkili ve ayrıcalıklı olma anlamını içerdiği görülmektedir.

Otorite kavramının bir yanıyla yadsınan/olumsuzlanan diğer yanıyla da yüceltilen anlamları BADEP eğitimine katılmış babalar tarafından da ifade edilmiştir. Babaların kavramın bu iki yönünü de babalık strateji ve taktiklerine yedirerek icra ettikleri görülmektedir. Babalar genel olarak otoriteyi aile içi ilişkilerin tanzimi için elzem görmektedirler. Ancak BADEP'li babalar, elzem olarak gördükleri otoritenin yadsınan anlamlarını açığa çıkaracak icralardan da kaçınmak istemektedirler. Örneğin TK için otorite baskı kurma/baskıcı olma ve bir konunun uzmanı olma ve aile üyelerine sözünü dinletme anlamlarına gelmekte; MB ise otoriteyi kurallar koyma ve kurallara uymayı sağlama, yaptırım tekeli ve sözün dinlenmesi olarak tanımlamaktadır.

"Otorite derken ben evde otorite miyim? Otorite derken baskıcı bir kurum muyum? Bizim aslında bir yanlış belki. Otorite farklı anlamlara da geliyor. Şöyle bir konu hakkında uzman bir kişi. Bir de otorite derken sürekli baskl kuran kişi anlamında otoriter. Sonuçta benim evde söylediğim şeyler dikkate alınıyor" (TK, 43 yaşında, Avukat, İstanbul).

"Bence biraz otorite olması gerekiyor. Çünkü aslında çocukları biraz da kurallar şekillendiriyor ve yönlendiriyor diye düşünüyorum. Yani kural olmadan bence olmaz muhakkak birtakım kurallar konmalı. Eeee bunda da eser miktarda bir otorite (gülüyor) olması gerekiyor. (...) Otorite bence sözünüzün dinlenmesi demek hani basit anlamda. Aile içinde bence sözünüz dinleniyorsa bence otoritersiniz. Evet otoriter. Yani otoriteyi inşa etmiş anlamında yani sözünüz dinleniyorsa söylenenleri yaptırabiliyorsanız karşı tarafa tabi şey değil hani ikna yoluyla birtakım şeyleri gerçek anlamda kabul ettirebiliyorsanız ve yaptırıyorsanız benim anladı̆̆ım otorite budur yani. (...) Otorite yetki demek anlamında değil mi biraz. Bilen" (MB, 41 yaşında, Binbaş1, İstanbul).

$\mathrm{Bu}$ anlamlara ek olarak EE için otorite, hedefler koyan ve üstün bir yargılama gücüne sahip kişi; ÜA için otorite, emrin inceltilmiş hali, bilgilendirilen kişi ve onay veren ya da son sözü söyleyen 
merci; HK için ise otorite, kurallar koyma, kontrol etmenin süreklileştirilmesi anlamına gelmektedir.

"Otorite başta olan bir şey değil bence en sonda olan bir şey. Mesela hani otorite kendini getiriyor. Kendisi direk gelen bir şey değil yani. Siz burada belli hedefler koyarsiniz. Belli uygulamalar yaparsinız. Bunlart yaparken siz hep işin içinde olursunuz. (...) Hem eşin hem çocukların hem de aldığın kararlar ne kadar olumlu olursa bu otoriteyi güçlendiriyor. (...) Yanlış karar almamaya çalışırım. Bunları yapıyor olmak otoriteyi doğruyor" (EE, 40 yaşında, Vestel Bayisi, İstanbul).

"Ricalar birlikteliği, emirlerin ricalar şekline dönüşmesi. Otorite budur bence. Emirlerin ricalara dönüşmüş şeklidir. Bana haber verecekler. İzin almayacaklar. (...) Son noktayı ben söylerim. Son noktayı ben söylerim. Onlar alternatifleri değerlendirirler" (ÜA, 44 yaşında, Oto Tamircisi, Eskişehir).

"Otorite deyince şunu çok net söyleyebilirim. Beni rahatsı etmeyen bir şey olmalı otorite dediğimiz şey. Benim iyiliğime olan bir şey olmall. (...) Otorite dediğiniz şey, bir kurallar zinciri değil midir yani. (...) Eşim mesela zaman zaman bana çok otoritersin der. Ya benim eşim galiba otoritersin dediğinde şunu söylüyor. Senin böyle çok keskin çizgilerin var diyor. Ak ise ak. Kara ise kara. Ak hiç gri olmaz mı? Birazcık beyaza çalmaz mı?" (HK, 45 yaşında, Okul Müdürü, İstanbul).

SG için otorite disiplini sağlamak, son karar mercii olmak, istenilen her şeyin yapılması ve babası anlamlarına gelmektedir. ST ise otoriteden bir yandan sertliği, dediğim dedik olmayı, ciddi olmayı ve aile üyelerini disipline etmeyi anlamaktadır. Benzer şekilde Sİde otoriteyi sözün arkasında durma ve güven olarak tanımlamaktadır.

"Yani otorite, aslında direk babam canlaniyormuş gibi sanki. Yani ne istiyorsa o oluyordu evde. (...) İstediği bir şey yapılması değil, karşı taraf istemiyorsa o, otorite değildir aslında. Otorite nedir? Yani evde alınacak olan bir karar varsa, bu karar mercii babadır. Fikir olarak aile bireylerine göre hareket eder. Olacaksa olacak, olmayacaksa bu en son karart veren gene odur düşüncesi" (SG, 35 yaşında, Muhasebeci, Ankara).

"Sertlik dediğim dedik. Öyle bir şey anllyorum. Ben yapamıyorum onu. Beceremiyorum. Ben otoriter olamiyorum bilmiyorum. Hani sertlik dediğim dedik, ben ne dersem o olur onu anllyorum otorite deyince. Otoriter baba, duygusunu belli etmeyen, mesafe koyan. Ha ciddi olunacă̆ zaman ciddi oluyorum" (ST, 40 yaşında, Odyolog, Ankara).

"Otorite dediğin şeyin arkasında durmaktır. Yani bir şeye olmaz diyorsan peşine olur dememen lazım" (Sİ, 43 yaşında, Şirket Müdürü, İstanbul).

OE için otorite, sözünün dinlenmesi ve kendisine itiraz edilmemesi anlamına gelmektedir. Aynı şekilde MT, otoriteyi sözünün dinlenmesi ve aile üyelerini disipline etmeyi anlamaktadır. Aynı şekilde MÖ için otorite, hâkimiyet kurmak ve söz sahibi olmak anlamına gelmektedir. 
"Otoritem vardır. Eşim benim istemediğim bir şeyi kesinlikle yapamaz. (...) Otorite benim için ailede sözümün dinlenmesi. Yani klzdiğım zaman o aileye baskı uygulayabiliyorum ben" (OE, 33 yaşında, Mağaza Müdürü, Eskişehir).

"Tabi ben otoritenin kendimde olmasinı istiyorum. Sonuçta hani en çok çalışan ben, en çok yorulan ben. (...) Otorite deyince benim kafamdaki deyince televizyonun kumandasinı ben alayım. Ben zapping yapayım" (MT, 43 yaşında, Oto Malzeme Bayisi, Ankara).

"Otorite deyince oraya hâkimiyet, söz sahibi olmak. Ha ben otoriter miyim. Iss yerinde otoriterim. (...) Ya benim babam evin içinde otorite $k u$ rar yani çok rahat kurur" (MÖ, 33 yaşında, İşçi, Eskişehir)

MS için otorite, kurallar koyan ve sözü dinlenilen kişi anlamına gelmektedir. Bu MS için otoritenin aşırılaşması zarar getirmektedir. Dolayısıyla yoğun bir otoriteden kaçınmaktadır. MY için otorite, kural koyan kişi anlamına gelmektedir. MY için otorite, doğru ve sağlıklı karar verme ve bunun sonucunda oluşan güven anlamına gelmektedir.

"Otorite baskın kişinin koymuş olduğu kurallar olarak anlyyorum. Şimdi otorite ne kadar otoriter olduğundur. Şimdi bazı konularda çok fazla otoriter olamıyorsunuz. (...) Kızım bana mukavemet gösterdi. Ben biraz bu konularda şey olsun istemiyorum. Ben dediysem, bir şey göstereceğim bir şey anlatacağım, ben dediysem dinleyecek" (MS, 42 yaşında, Öğretmen, Eskişehir).

"Otorite kural koyucu. Kuralları belirleyen. Şimdi nedir bu anne babadır. Yine ortak şekilde. (...) Kimin alaniysa kuralı da o koymalı" (MY, 40 yaşında, Kuyumcu, İstanbul).

Mülakatların da gösterdiği gibi otorite, bir yandan kural koyan, baskı uygulayan, denetleyen anlamlarını içermekte bir yandan da bilge, bilen, yol gösteren ve disipline eden anlamları içermektedir. Bu bağlamda otoritenin bir yanıyla kültür-üretici anlamı ön plana çıkarken; diğer yandan da otoriterliği çağrıştırdığı görülmektedir. Aksu (2011) otoritenin yaşamın üretkenliğinin sürdürülmesi, türün yeniden üretiminin sağlanması ve yaşam alanının genişletilmesi gibi birçok alanda 'arttırıcı' bir etken olduğunu belirtir. Bu bağlamda BADEP'li babaların -programın amacının aksi yönünde- otorite taleplerinden vazgeçmedikleri görülmektedir. Ancak babalar, otoriter olarak gördükleri birinci anlamdan uzaklaşmakta fakat ikinci anlamı da yüceltmektedirler. Babalar anladıkları şekliyle otoritelerini üretmek için birçok farklı taktikler de kullanmaktadır. Bir yandan kişi olmak; yaptırım uygulamak; karara son noktayı koymak; dediğini yapmak; baba rolünü oynamak; ciddileşmek; şiddet uygulamak ve kızmak gibi yadsınabilecek teknikleri kullanmaktadırlar. Diğer yandan sözünü dinletmek; hedef koymak; çabalamak; güven vermek; sorumlu olmak; doğru karar almak; kural koymak; ikna etmek; zaman aylrmak; ortak karar vermek; planlamalar yapmak; talepleri dile getirmek; annenin onayı başvurmak; tanımak gibi olumlu karşılanabilecek teknikleri kullanmaktadırlar. Otorite taleplerinden vazgeçmeyen babalar stratejik bir dönüşüm ile BADEP sonrasında aile üyeleri üzerindeki otorite üretici taktiklerini dönüştürmüşlerdir. Belirtilen ilk taktikler açık otorite stratejisi olarak ikinciler de örtük otorite stratejisi olarak adlandırılmıştır. Özellikle otoritenin yadsınan anlamlarından uzaklaştıkları görülmüştür. İlerleyen paragraflarda babaların bu stratejilerden neler anladıkları açık bir şekilde dile getirilmiştir. 


\subsubsection{Açık Otorite Stratejisi}

BADEP babaların otoriteleriyle aile üyeleri üzerinde tahakküm kurmamaları ve aile üyelerinde herhangi bir travmaya yol açmamaları için babalık pratiklerine müdahale etmektedir. Bu çerçevede babaları alışageldik, aile üyelerini önemsemeyen ve onlara şiddet uygulayan baba tipinden uzaklaştırma amacı gütmektedir. Nitekim örneklemimizi oluşturan babaların da bu amacı içselleştirdikleri görülmüştür. Ancak yine de babaların bütünüyle açık otorite stratejisinin tekniklerinden vazgeçtikleri söylenemez. Nitekim örneklemi oluşturan babaların zaman zaman otoriterlik sıfatlarını ortaya çıkararak otorite tesisine çabaladıkları görülmektedir. Örneğin MS, zaman zaman aile üyeleri ile olan ilişkisinde babalığını vurgulamak, kızmak ve şiddet öğelerini devreye sokmak gibi teknikleri kullanmaktadır. Babalığını vurgulamak, yapılan yorumların doğallığında doğru olduğunu ve aile üyelerinin babanın kararlarına uymalarının bir zorunluluk olduğunu başka bir deyişle babalığını vurgulayarak sözünün dinlenmesi talebini dile getirmektedir. Kızarak ise çocuğa kurallar hatırlatılmakta ve herhangi bir kural ihlalinden vazgeçmesi istenmektedir. Bunlar yeterli gelmediğinde ise şiddet öğelerini devreye sokarak çocuğun ihlalden vazgeçmesi sağlanmaktadır.

"Ben dediysem, bir şey göstereceğim bir şey anlatacağım, ben dediysem dinleyecek. Yani onu istiyorum o zaman. Ondan sonra, olacak dedim olmayacak, olacak olmayacak en sonunda ben kizdim. Ondan sonra bu sinirli bir şekilde defterlerini çıkartmaya başladı. Tabi bana tripler. Artistikler falan sunlar bunlar. Ben daha da kızdım bu defa. (...) Söylüyorum mesela oyuncaklarını kaldır diyorum. Kaldırmıyorsa, ben biraz daha radikal beni kararlarım. Onun sevdiği oyuncaklar var onlart tekmeliyorum. Mesela çantasinı ortaya attiysa çantaya bir tane tekme atıyorum, çanta uçuyor gidiyor bir yerlere" (MS,42 yaşında, Öğretmen, Eskişehir).

HKA'da BADEP'ten öğrendiklerini tam olarak uygulayamadığı zamanlarda kızmak, bağırmak ve hakaret etmek gibi teknikleri kullanmaktadır. HKA, kızarak çocuğunu davranış değiştirmeye zorlamakta; bağırma ve hakaret etme ile de çocuğunun yapmış olduğu kural ihlallerini cezalandırmaktadır. Böylece çocuklarının kural ihlal etmelerinin önüne geçmeye çalışmakta ve sözünün dinlenmesini sağlamaktadır.

"Biz akşam eve gidiyoruz yorgun oluyoruz, biraz tepkilerimiz sert oluyor çocuğa. Sert derken, bağırıyoruz, kizıyoruz. (...) Çocuk bazen lavabodan ellerini yıkamadan çıkıp geliyor diyorum ki 'ne kadar pis adamsin sen!' daha sonra BADEP'te anlatılan 'çocuğun karakterine yönelik suçlamalarda bulunma' ne demek gerekiyor orda, sen ellerini ylkamadın bu beni çok rahatsız etti ellerini yıkarsan daha iyi olur, şeklinde konuşmak daha iyi. (...) Eksik yanım çok çabuk kızmam. Yani şöyle çocuktur bu anlama kapasitesi ona kadardır şimdi ben karşımda kişiyi yetişkin olarak görmek istiyorum. O var yani. Karşımdaki çocuk 8 yaşıııda ben onu 8 değil de 18 yaşında veya 20 yaşında bir yetişkin gibi görerek aslında o küçük ama ben yetişkine göre bir cevap almak istiyorum ama o da olmuyor ve benim anlatmam gerekiyor. Sürekli de aynı şeyi anlat, anlatmak beni sinirlendiriyor" (HKA, 36 yaşında, Memur, Eskişehir).

ÖY her ne kadar aile üyelerine karşı zor unsurlarından kaçınsa da mizacı gereği bazen katı kuralcı olmak, öfkelenip bağırmak ve bazen şiddete başvurmak tekniklerini kullanmaktadır. Katı kuralcı olmak ile aile üyeleri arasındaki ilişkileri sağlayan kurallarda herhangi bir esnemeye ya 
da kural ihlaline müsamaha göstermemeyi ifade etmektedir. Ayrıca kural ihlallerinde öfkelenip bağırarak ve kimi zaman şiddete başvurarak aile üyelerini korku nesnesi ile karşı karşıya getirmekte, böylece aile üyelerini sözünü dinlemesi konusunda baskılamaktadır.

"Babam daha agresifti. Çok dürüst, çok titiz, çok düzenli. Dolaylsıyla en ufak bir hatayı bile tolere etmeyen bir yapısı vardl. Bana da tabi o yansımıştı. (...) Ama bunları yapacağım derken de kırıcıydı. Hani hiç toleransı yoktu. (...) Babam mesela en çok eleştirdiğim husus, bana yaptı̆̆ eleştirilerin yani eleştiriden öte dövmeye giden şeyler çocukken tabi, kalabalık bir ortamda da yapardı. (...) Doğruysa doğru illa öyle olacak. Şunu yeri burasiysa hep burada duracak. Şurada durursa olmaz bu. (...) Şimdi ben yapı olarak biraz rahat öfkelenen bir insanım. (...) Çocuklarıma olan bazen öfkem hani aşırı oluyor hani bir çocuk sonuçta. Ama biz bir yetişkin insandan beklediğim şeyleri bekleyip, onu da yapmayınca kızıyordum. Sonra da kendim de üzülüyordum tabiî ki çok doğal olarak. (...) Belki ses tonumuz artmıştır. Arttı yani. Bağırmak” (ÖY, 41 yaşında, Mühendis, Eskişehir).

Genel olarak asabi olan Sİ, eğitim sonrası oldukça yol kat etmiş olsa da kimi zaman korkutmak, tehdit etmek ve kişiliğinin sert ve asabi oluşunun arkasına sığınmak tekniklerini kullanmaktadır. Korkutmak ile kural ihlalinde çocukların korku nesnesiyle karşılaşacaklarını onlara belirtmektedir. Böylece çocukların kurala uymalarını başarmaktadır. Aynı şekilde tehdit ederek çocuğun istenmeyen davranışı gerçekleştirmesinin önüne geçmektedir. Sert ve agresif olarak bağırıp çağırma ile etrafına korkulan kişi izlenimini yaymaktadır.

"Ee peki tamam oğlum dedim. 'Ben 18 yaşındayım, kendi kararlarımı kendim verebilirim' dedi. 'Tamam oğlum' dedim. 'Kendi kararların kendin verebilirsin. Ama o kararlarin arkasinda durmak zorundasin'. 'Nastl yani' dedi? Dedim ki. 'Bundan sonra sponsorluğunu ödemem. Internetini ödemem. Sadece cep telefonunu öderim'. (...) Kavga yumruk yok. Oğluma sadece 13 yaşında bi fiskem vardır. Bir fiskem vardır. Ben şuna inanırım. Çocuğu dayak arsızı yapmaman lazım. Yani bir kere canını acıtırsın, hani bu şey gibidir. Hani soba, soba dersin. Clz dersin falan, ama yaklaşır ona bir kere yanar ondan sonra yaklaştıramazsin. Onun gibi yani. O hani bakmamdan çekinir normalde. Ama tabi belirli yaştan sonra artık hani genç nesil ama asla hani şiddete şey değilim. Ha dediğim gibi sinirliyim, bağııırım, çă̆ırırım. (...) Dediğim gibi ben agresif biriyimdir falan da. Dediğim gibi ben her konuda anlayışl biriyimdir. Ĕger istemediğim bir şey yaptıysa en büyük ceza bă̆ırmak değil susmaktır. (...) Olumsuz manada söylüyorum. Çok tez canliyım. Yani çabuk sinirlenebilen bir tipim" (Sİ, 43 yaşında, Şirket Müdürü, İstanbul).

OE her ne kadar BADEP sonrası aile üyeleri üzerinde baskı kurmanın zararlı etkileri olduğunu öğrenmiş olsa da fevri çıkışlar göstermek, sembolik şiddet kullanmak ve şiddet uygulamak tekniklerini kullanmaktan tam anlamıyla vazgeçebilmiş değildir. OE fevri çıkışlar göstererek aile üyelerinin korku nesnesi olarak baba ile karşılaşabileceklerini onlara belirtmektedir. Böylece onları kurallara uymaları hakkında uyarmaktadır. Sembolik şiddet kullanarak ise kural ihlallerine karşı çocuklarını uyarmaktadır. Uyarmanın yetersiz kaldığını hissettiğinde ise şiddete başvurarak kuralların yürürlügünü sağlamaktadır.

"Çok ani fevri çıkışlarım var. Anlık. İşte ne diyelim üç ayda bir diyebi- 
liriz buna. Yıla vurduğunuzda dört kere beş keredir. Fevri patlamalar. (...) Preslerin hortumlarl vardır. Babam bir tane onunla vurdu bana yaptığım şakadan dolayı. Ama acıtmadı o. Babam bana acıtmak için vurmad. Babamin o hareketi öyle bir dokundu ki durmam gerektiğini o zaman ögrendim. O sembolikti aslında. Hortum sembolikti. Canımız yanmadl. (...) Eymen'e en büyük şiddet mi diyelim ona şiddetim şu şekilde şu (işaret parmağını başparmağına sürterek ileri gitmesini sağlama). $E y$ men'e ben bunu yaparım şöyle yaparım uyarı. O bilir. Baba sen bana uyarl verdin ya. Tik diyelim. Parmakla tık. Benim bugüne kadar yaptığım en büyük şey budur. (...) Yani kızdiğım zaman o aileye baskı uygulayabiliyorum ben. Bir kere yaşadım bunu. Eşimle bir tartışma yaşadım. Siniyi getirdi koydu önüme. Bir şeyden tartı̧̧ma çıktı o gün. O kadar çok sinirlendim ki. Elimdeki kaşı̆̆ı siniye vurdum. Sinin boyası kalktı. O boya çok kolay kalkan bir şey değil. o kadar sert vurmuşum ki boya kalkmış. O sini hala duruyor" (OE, 33 yaşında, Mağaza Müdürü, Eskişehir).

ÜA, BADEP sonrasında aile üyelerini çekip çevirme konusunda oldukça yol kat ettiğini belirtmiş olsa da, ara sıra uyarmak, tehdit etmek ve dayak atmak tekniklerini kullanmaktadır. Uyararak çocuğun kuralı yerine getirmesini talep etmekte, ancak çocuk ihlal etme davranışı sergiliyorsa çocuğu tehdit etmektedir. Bu teknikler yetersiz kalınca ÜA, kuralı uygulaması için çocuğa dayak atmaktadır.

"Mesela yüzüne hiç vurmadan, yani vücudunda iz yapmadan bir şiddet
uygulayabilirsiniz. Fiziki şiddetten bahsediyorum. Mesela cetvelle eline
vurdum. Ş̈̈yle ben bunu birkaç defa ikaz ettim. Odanı topla, masanı top-
la, masanı topla. Ben buna söyledim tabi. Bak bu senin toplamaman be-
nim hoşuma gitmiyor, üzülüyorum. Yani uygun şekilde anlatmaya çalışı-
yordum. Bu beni anlamadl. Dedim ki bir daha yaparsan bunu farklı bir
şekilde söyleyeceğim sana bunu dedim. Bağırmadan, çağırmadan. O
tekrar yine aynı devam etti. Bira hafta sonra çektim kenara. Tabi başka
bir suçu ile birleştirerekten. Gel bakalım oğlum dedim sen neden böyle
yapıyorsun. Sana defalarca söyledim. Getir cetveli. Getirdi. Tahta cet-
velle. İkişer tane ellerine vurdum. Sebebini de biliyorsun. Tabi çok üzül-
dü. Gözleri de dolu dolu oldu. Ağlayamadı da. Suçunu biliyor çünkü. De-
dim bundan sonra tekrar böyle bir şeyler karşılaşırsam ciddi sıkıntı olur
dedim. O gün bu gündür masa çok düzgün bir şekilde toparlantyor ve
hareketlerine daha çok dikkat eder oldu” (ÜA, 44 yaşında, Oto Tamir-
cisi, Eskişehir).

Babalar her ne kadar BADEP'in hedef çıktılarını içselleştirmiş olsalar da kimi zaman eğitim öncesi babalık icra tekniklerine dönebilmektedirler. Bu onların genel olarak çaresiz kaldıklarında başvurdukları tekniklerdir. Babalar için bu teknikler aile üyelerinin kurallara uymalarını sağlayan şiddet içeren bildirimler; aynı zamanda onların katı kurallara uymaları için zor ve bask1 uygulanması, başka bir deyişle aile üyeleri bir şeyleri zorla yaptırtma, onları korkutma anlamlarına gelmektedir. Bu teknikler kümesinin açık otorite stratejisi olarak adlandırıldığ tilmiştir. Bu bağlamda açık otorite stratejisi, otorite sembollerinin babalık icrasında kendini saklama gereği duymadığı tarz olarak tanımlanabilir. Başka bir deyişle babalar için açık otorite stratejisi, babaların taleplerini aile üyelerinden gizlemeden açıkça gösterip belirtmeleri ve aile üyelerinin bu beklentileri yerine getirmesi için gerektiğinde zora başvurmaları ve hatta şiddet uygulamaları anlamlarına gelmektedir. Daha çok babaların gücünün (power) belirginleştirildiği 
bir otorite stratejisidir. Özellikle BADEP sonrası, babaların bu stratejiden mümkün olduğunca uzaklaşmaya çalıştıkları görülmektedir. Açık otorite stratejisi, otoritenin yetkili ve ayrıcalıklı olma ile emir verme hakkını ön plana çıkaran teknikleri içermektedir. BADEP'in, babaları bu uygulamalardan vazgeçirerek aile üyeleri üzerinde baskılarının kalmamasını amaçlamaktadır. Nitekim bu konuda başarılı olduğu da görülmektedir. Ancak babalar otorite taleplerinden vazgeçmemekte sadece otorite sahibi olduklarını manipüle etmektedirler. Bu kapsamda babaların uygulamış oldukları örtük otorite stratejisi ilerleyen kısımda açıklanmıştır.

\subsection{2. Örtük Otorite Stratejisi}

Otorite babalar için bir yandan baskı kurma anlamına gelirken diğer yandan aile üyeleri arasındaki ilişkileri biçimlendirebilmek için önemli/zorunlu bir kavram olarak görülmektedir. $\mathrm{Bu}$ kapsamda BADEP'in otoritenin arttıran, bilgelik ve ilişkisellik gibi anlamlarını ön plana çıkardığı ve ayrıcalıklı ve yetkili olma ve emir verme hakkı anlamlarını da görünmez kıldığı söylenebilir. BADEP sonrasında babalar bilen, uzman, disipline eden, güven veren anlamlarındaki otorite anlayışıyla aile üyeleri arasındaki ilişkileri biçimlendirme gayretine girişmişlerdir. $\mathrm{Bu}$ anlamları ön plana çıkararak babaların otorite taleplerinde bir gerileme olmadığı aksine aile üyeleri üzerinde otoritelerinin bu anlamlarını belirginleştirilerek 'patria potestas'larını perçinledikleri görülmektedir. Nitekim MÖ, ikna etmek, anlatmak, tercihleri çocuğa birakmak ve ölçütler gelişstirmek tekniklerini kullanarak otoritesini yeniden yapılandırmaktadır. Çocuğunu ikna ederek onun aile içi kurallara uymasını sağlamaktadır. Ayrıca seçenekler sunarak onun kurallara farklı şekillerde uyabileceğini de belirtmektedir. Böylece çocuğun hem kuralın sorumluluğunu üstlenmesini hem de özgüvenini geliştirmesini başarmaktadır. MÖ, çocuğu hakkında yorumlamalarda bulunabilmek için ölçütler geliştirmekte ve karşılıklı ilişkilerini kişisellikten çıkarmaktadır.

"Çocuk içeride televizyon izleyeceğim diyor. Sevdiği bir çizgi film var. Akşam yemeğine gelmiyor. (...) Dedik tamam oğlum şu anda gel. Akşam yemeğimiz bu saatte. Çünkü önceden beri hep bu saatte yiyorduk. Farklı bir saatte yedik mi diye sordum. Yok dedi baba dedi. Peki şimdi neden farklu bir saat istiyorsun. Ondan sonra dedi yok dedi. Ondan sonra şu anda gidiyoruz yiyoruz yemeğimizi yarn hep beraber karar verelim madem çizgi film bu saate geliyorsa ya bir saat ileri alalım ya da bir saat önceye alalım yemeğimizi. Çocuk ikna oldu. (...) Elindeki malzemeyi kırmadan kullanmak lazım. E şimdi sen bunu kırdiğın zaman ben sana bunun yenisini alamayacağım. İster kırık kullan ister kullanma. O senin tercihin. (...) Ve bir gün bir de biz buna çizelge yaptık. Bir sayfa yaptık. Yatak toplama, çantayı düzenleme, dolap düzenleme. Üç tane kuralı verdik. Günleri yazdlk. Birinci gün şunları yaptt. Artı. Bunların altına yazdik. Oyuncak araba, dondurma, çikolata. Hangisine önce ulaşırsa onu aldı. Bunu aldı o oyuncağı ona hiç dokunmuyor. Her zaman oyuncak klran çocuk o oyuncağa hiç dokumuyor" (MÖ, 33 yaşında, İş̧i, Eskişehir).

Benzer bir şekilde MB şiddetten uzak durmak, sözleşme imzalamak ve ikna etmek tekniklerini kullanmaktadır. Aile üyeleri üzerinde otoritenin varlığına ihtiyaç duyan MB, şiddetten uzak durarak çocuklarının baskı ve zor gibi öğelerle kuralları yerine getirmelerinin önüne geçmektedir. Ancak ikna ederek onların kurallara riayet etmelerini sağlamaktadır. MB şiddetten kaçınıp çocukları kurala uymaları konusunda ikna edince çocuklar babanın taleplerini karşılamaktadırlar. Ayrıca aile üyeleriyle sözleşme imzalayarak aile üyelerini kuralların sorumluluğunu almaya gönüllü hale getirmektedir. Böylece sözünü dinletebilmektedir. 
Zaman zaman açık otorite stratejisini kullanmaya çok az meyilli de olsa MS, gözetleme yapmak, aile üyelerine sorumluluk yüklemek ve eşini tanımak tekniklerini kullanmaktadır. Gözetleme ile MS çocuğunun kurmuş olduğu arkadaşl1k ilişkilerini denetleyerek bu ilişkinin herhangi bir kural ihlaline yol açmamasını sağlamaktadır. Çocuğuna sorumluluklar yükleyerek istenilen işleri yapabilme becerisini geliştirmektedir. Eşini tanımaya çalışarak karşılıklı olarak isteklerinin neler olduğunu anlamanın yolunu bulmaktadır. Böylece MS ailesindeki ilişki ağlarını avuçlarının içine alıp aile üyelerini her daim gözetim altında tutabilmektedir.

"Kendi arkadaş kurduysa hani kendine bir arkadaş ortamı, evin olduğu yerde ya da okulunda yeni bir arkadaşlık kurduysa ailesiyle tanışmaya çalışlyoruz. Acaba annesi nasıl biri, babası nasıl biri. Ondan sonra kendi şeyimizde de ortamimizda etrafimizda bizim gibi olan aileleri tercih ediyoruz. Onların yaşıtlarıyla, çocuklarıyla görüş̧ürüyoruz. (...) Çiçeği sulamıyorsa ĕger köpek gelmeyecek. Artık biliyor. Ya da ne bileyim bakmakla sorumlu olduğu bir şeyi konuşuyoruz tamam diyor baba. Ama yapmiyorsa eğer işte devamindaki yapilacak olan gelmiyor mesela. (...) Ya şimdi artık birbirimizi tanıyoruz. Tanıdıktan sonra da hani eşimi bu saatten sonra şöyle yapacaksın, bunu getireceksin, ya da kızıma hayır bunu istemiyorum ben kesinlikle bunu yapmayacaksin gibisinden şeyler. Hani ne istediğimizi biliyoruz en azından" (MS, 42 yaşında, Öğretmen, Eskişehir).

Uzun bir zaman babalık yapamadığını düşünen SG, BADEP sonrası doğruyu anlatmak, gerekçe sunmak ve alternatif çözümler önermek tekniklerini kullanmaya başlamıştır. Doğruyu anlatmak ve çocukla konuşmak babanın taleplerinin ve kurallarının çocuğa aktarılmasını kolaylaştırmaktadır. SG gerekçeler sunarak çocuğa bu beklentilere neden uyması gerektiği bilgisini aktarmaktadır. Böylece çocuk neden sonuç ilişkisini kurarak içsel disiplinini geliştirmektedir. Herhangi bir sorun karşısında alternatif çözümler önermek ile çocuğun talepleri ile kendi beklentileri arasında bir denge ortaya çıkarmaya çalışmaktadır.

"Ama şimdi TV örneği, şöyle oluyor şimdi. Örneklerle, şimdi sen ne yaptın burada diyorum. Böyle böyle yaptım diyor. Eveet. Bu yaptı̆ğn doğru bir şey miydi? Sana göre doğru olabilir ama bana göre doğru değil. Annene göre de doğru değil, dedene ve babaannene göre de doğru değil bu yaptığın hareket. Demek ki yanlış bir hareketmiş. Şimdi yapmış olduğun yanlış hareketten dolayl ben sana ceza versem sen içeri gitsen otursan TV'yi biz izlesek desem sen TV'yi izlemeyeceksin. Doğru mu? Doğru. Peki ben sana bu cezayl vermek zorunda miyım? verebilirim, şu anda sana bu cezayl verebilirim. İçeri gönderebilirim seni? Şu an da sen artık TV'yi izlemeyeceksin. Şu an da on dakika sana ara diyorum. İçeri gideceksin biz izleyeceğiz. İçeri gideceksin on dakika süren dolduktan sonra geri geleceksin dediğimiz zaman bunu yaptırlyorum mesela. Gidiyor, on dakika sonra tekrar geliyor. Daha rahat artık ona tepkimi gösterebiliyorum bağırmadan, çağırmadan. (...) Biri dayak atarak yapıyor bunu. Biri de sadece onun anlayabilecek olduğu, ses tonunu bile değiştirmeden, sen tonunu, çeşitlilik sunarak, ya da ne bileyim değişik alternatif yollardan hareket ederek onu ona anlatmak var (...) Bu olmayacak dediğiniz zaman onun çok şey yapardı zıddını şeyleri, yapmaya başlardı. 'Ama bu olmayacak ama şöyle olabilir. Bu, bu şekilde olmaz ama şu şekilde olabilir. Bunu bu şekilde yapma şu şekilde yapabilirsin' demek. 
Ona bir çözüm alternatifi sunmak, bu kuralları almamızı çok daha yardımcı oluyor yani" (SG, 35 yaşında, Muhasebeci, Ankara).

BADEP öncesi çocukları idare etme konusunda oldukça zorlanan SA, programdan sonra kismi olarak karar alma süreçlerine aile üyelerini katmak ve seçenekleri önceden belirleyerek kontrolü elden bırakmamak tekniklerini kullanmıştır. SA ilk teknik sayesinde çocuklarıyla ilgili almış olduğu kararların çocuklar tarafından yerine getirilmesini sağlamaktadır. Çünkü çocuklarda kararları kendileri aldıklarına dair bir inanç geliştirmektedir. Arka planda baba, siyaset yaparak kontrolü elinden bırakmamaktadır. İkinci teknik sayesinde ise SA olacakları öngörüp hamlelerini belirleyerek çocuğun neyi seçeceğine müdahale etmektedir.

"Biraz uyanık davraniyoruz. Ne yapıyoruz, atıyorum. Top alınacak demi? Futbol topu mu basketbol topu mu değil de ne renk alacağımızı kararlaştırmaya çalışıyoruz. Ya da işte ona legalleştirme diyelim. Mesela çok fazla istemediğimiz bir şey talep ediyorlar örneğin. Hani ne bileyim şunu şöyle yapabilir miyiz? Tercihi onu mu yapalım şu mu yapalımdan ziyade tercih işte biz parka gideceğiz de çocuklar parkta nelerle oynamak istersiniz? Hani iki tane park seçeneği sunsan biri diyecek $k i$ buna gidelim, biri diyecek ötekine gidelim. Neyi sağlamış oluyorsun. Bizim dediğimiz yapıyorlar ama legalleşiyor. Mesela biliyorum ki sağlıksız bir şey yemek isteyecek. Cips isteyecek. Çok da mahrum birakmak istemiyorum. Ayda bir defa aliyorum. Birikiyor, birikiyor, birikiyor. Tam böyle şımarıklı̆̆ın dibine vuracakları bir anda alıp sakliyorum evde. Çocuklar oturursanız size acayip sürpriz geliyor. Baba cips mi? Legalleşiyor. Bir açlyorsun cipsi tamam o gün bitti. Artık emrinde yani. Kara$r l$ istediğin gibi al karşıllklı. Ama mutlaka söz sahibi ediyorum onları da. Nerede işte renk seçiminde. Hangi oyuncak seçiminde" (SA,41 yaşında, Öğretmen, Eskişehir).

Mülakatların analizi sonucunda görüldüğü gibi babalar, BADEP sonrası otorite üretici tekniklerde farklılaşmalara gitmişlerdir. Özellikle aile üyeleri üzerinde baskı ve zor unsurlarını belirgin kılmaktan uzaklaşmaya çalıştıkları görülmüştür. Babalar, bu teknik beceriler sayesinde çocukları yönetebilme konusunda oldukça başarılı olduklarını ifade etmişlerdir. Ancak babalar bu teknik ve stratejik dönüşüm sonucunda otoritelerinden vazgeçtikleri sonucu çıarılamaz. Aksine babalar bu yeni strateji sayesinde otoritelerini mikro alanlara kadar ulaştırabilmektedirler. Nitekim TK, SA, MB örnekleri bunun en güzel yansımasını teşkil etmektedir. Dolayısıyla BADEP'li babalar, otoriteden vazgeçme yerine otorite üretici pratiklerini dönüştürmektedirler. Böylece hem aile üyelerini daha fazla oranda gözetim ve denetim altında tutmakta hem de onlar üzerindeki belirleyiciliklerini tahkim etmektedirler. Babaların kullanmış oldukları bu tekniklerden hareketle babalar için örtük otorite stratejisi aile üyelerinin kuralları öğrenmesi sürecinde şiddet ve zor unsurlarının devre dışı bırakılması anlamına gelmektedir. Başka bir deyişle karşılıklı iletişim ve uzlaşı temelinde aile üyelerince kuralların içselleştirilmesi; şiddet ve zor unsurları olmadan çocuğu kontrol edebilme ve çocuğun davranışlarına müdahale edebilme; aile üyelerini birey olarak görüp kişiliğe zarar vermeden iş yaptırtabilme; uyanık olma ve siyaset yapma anlamlarına gelmektedir. Örtük otorite stratejisi, uygulamalar esnasında otoritenin varlı̆̆ını gösterecek hiçbir sembolün pratiğe dökülmemesi ancak otoritenin yine de kuralların içselleştirilmesini sağladiğ veya derinden işlediği tarzıdır. BADEP'li babalar bu stratejiyi yaygın bir şekilde kullanarak otoritelerinin görünürlüğünü ortadan kaldırmaktadırlar. Böylece babalar aile üyelerinin gözünde 'otoriter' tipinden kurtulmakta ve otoritelerini üretmeye devam etmektedirler. 


\section{Sonuç}

Son iki yüzyıldır yaşanan birçok farklı faktörün farklı derecelerde etkisiyle aile dönüşmüştür. Ailenin reisi ve bir üyesi olarak babaların varlığ 1 ve otoriteleri farklı düşünsel mecralardan eleştirilmiş veya saldırılara uğramıştır. Feminizmin kötücülleştirdiği baba imgesi, aydınlanma düşüncesi ve yaşanan modernleşme hareketleri sonucunda aile üzerindeki belirgin etkisinin/gücünün azaldığı düşünülmektedir. Nihayetinde ise ortadan kaldırılması hedeflenmektedir. Nitekim 20. yüzyılda 'babasız toplum' idealleri ortaya çıkmıştır (Thoma 2011) 'Babasız toplum' arzularının hakim olduğu son yüzyılda dünyanın birçok yerinde kaybedenin baba olduğu Thernborn (2004) tarafindan açık bir şekilde ifade edilmiştir. Sonuç olarak günümüz dünyasında, kültürel olarak, ailede otoriteyi tekelinde bulunduran kişinin baba olduğu düşüncesinin sarsıldığ söylenmektedir (Sancar 2011). Oysa bu çalışma, bu iddialara radikal şüphe ile yaklaşmış ve babaların otoritelerindeki dönüşümün farklı bir hikayesini anlatmaya çalışmıştır. Makalede, otorite kavramının yeniden tanımlanması ve kavramsal zenginliğinin öne sürülmesi ile otoritenin kültür üretici yönü belirginleştirilmiştir. Akabinde ülkemizde yaygın bir şekilde uygulanan BADEP programına katılmış babalar örnekleminden hareketle babaların otoritelerinde herhangi bir azalma ya da ortadan kalkma durumunun olmadığı açık bir şekilde ortaya konmuştur.

BADEP'li babaların, kültürel alışkanlıklarını yeni yaşam dünyalarında da sürdürdükleri ve baba olmayı kültürün gereklerini yerine getirme olarak gördükleri ortaya çıkarılmıştır. Baba olmak bir erkeğin biyolojik ya da kurumsal olarak edindiği çocuğuna yönelik kültürce sinırları çizili babalık pratiklerini yerine getirmesiyle kazandığ yeni toplumsal pozisyon olarak tanımlanmıştır. Ayrıca çalışmada, babaların otoriteden ne anladıkları da ortaya çıkarılmıştır: Otoritenin yetkili ve ayrıcalıklı olma anlamlarının yanı sıra aile ilişkilerinin sürdürülebilmesi için güven üreten, yargılama becerileri geliştiren, ilişki kurulmasını sağlayan ve arttıran, bilen gibi anlamları olduğu görüldü. Bu anlamlardan hareketle otorite tüm ilişkilerin kategorik zemini ya da ilişkilerin ortaya çıkabilmesinin koşulu olarak tanımlandı. Babalar, sadece yeni olanın icrasını performe etmemekte aksine tarihsel olarak kendilerine aktarılan babalık mirasını da göz önüne alarak bir uzlaştırma eğilimi sergilemektedirler. Babalar, süreç içerisinde meydana gelen ilişkisel değişiklikleri kendi çıkarlarına uygun bir şekilde araçsallaştırmaktadırlar. Dolayısıyla BADEP'e katılmış babalar, öğrenmiş oldukları beceriler ile otoritelerini yeniden üretmenin yeni yollarını keşfetmişlerdir.

Babalar, aile içerisinde nizamın sağlanabilmesi için otoritenin varlığına ihtiyaç duymaktadırlar. Ancak otorite kavramını ilk etapta otoriterlik olarak algıladıklarından dolayı bu tarz bir otorite sahibi olmak istemediklerini de belirtmektedirler. Başka bir deyişle BADEP'li babalar için otoritenin farklı anlamlar taşıdığ 1 görülmüş̧ür. Bir yandan 'baskı kuran ve kaçınılan kişi', 'otoriter' olarak anlaş1lırken; diğer yandan da 'uzman, bilen, bilge, sözü dinlenilen, güvenilen kişi' olarak anlam bulmaktadır. Dolayısıyla BADEP'li babaların zihinlerinde ikili bir otorite kavramının yer aldığı bulgulanmıştır. Dolayısıyla BADEP'li babalar otoritelerinden vazgeçmemiş ancak yaşanan toplumsal dönüşüme eklemlenebilmek için otorite icralarında stratejik ve taktiksel yeniliklere başvurmuşlardır. Çalışmada bu yenilikler ise örtük ve açık otorite stratejisi olarak adlandırılmıştır. Çalışmada birçok tekniği tespit edilen bu otorite stratejiler de şu şekilde tanımlanmıştır: Açık otorite stratejisi, otorite sembollerinin uygulama esnasında kendini saklama gereği duymadı̆̆ tarza karşılık gelirken, örtük otorite stratejisi, otoritenin uygulamalar esnasinda hiçbir sembolünün pratiğe dökülmediği ancak gücünden hiçbir şey de yitirmediği veya derinden işlediği tarza karşılık gelir. BADEP'e katılmış babalar açık otorite stratejisinin aile üyeleri arasındaki ilişkiyi zedelediğine ve onların travma yaşama olasılığını artırdı̆̆ına ikna olmuşlardır. Bu nedenle babalar ikinci stratejiyi kullanmaya başlamışlardır. 
Babaların her iki otorite stratejisi ile otoritelerini yeniden ürettikleri ama özellikle örtük otorite stratejisi ile daha fazla otorite ürettikleri görülmektedir. Örtük otorite stratejisi en az açık otorite stratejisi kadar -eğer koşullar müsaitse- otoriterleşmeyi doğurmaktadır. Başka bir deyişle aile üyelerinde rıza üretilerek babaların tahakkümü görünmez kılınmıştır. Bu sayede babalar, otorite üretme pratiklerini örtükleştirerek günün koşullarına adapte olmuşlardır. Böylece aile üyeleri hem belirgin şiddet pratiklerinden uzak tutulmakta hem de babaların otoritelerine razı edilmektedirler. Bu atalarından aldıkları mirasın yadsınarak yeniden yüceltilmesidir. Babaların aile içindeki pozisyonuna dönük modernleştirici saldırılar, bu pozisyonun yeniden yerleştirilmesi sürecini doğurmuştur. 'Baba otoritesini' yeniden biçimlendirmek isteyen modernist müdahaleler karşısında babalar, binlerce yıllık babalık mirasını basiretleri ile yeniden üretme eğilimi sergilemektedirler. Günümüz modern babaları, yeni şişede eski şarap atasözüne uygun bir şekilde bir yandan modernleştirici talepleri yerine getirmekte; diğer yandan da atalarının mirasını sürdürerek modernliğin kültürel aptal ideolojisini yerle bir etmektedirler. Babalar bir yandan yeni babalık icralarını performe etmekte diğer yandan da yeni babalık icralarını alışageldikleri ilişki ağlarını üretmek için kullanmaktadırlar. Kısacası günümüz modern babaları yeni babalık icraları ile aile üyeleri arasındaki ilişkilerin biçimlendirilmesinde 'patria potestas' anlamındaki tarihsel pozisyonlarını yeniden üretmektedirler.

\section{KAYNAKÇA}

"Father". Online Etymology Dictionary. Source: $<$ https://www.etymonline.com/search?q=father $>. A C ̧ E V$ : Baba Destek Programı Bilgilendirme Broşürü. Kaynak: <http://www.acev.org/docs/default-documentlibrary/badep.pdf?sfvrsn=2>.

Adak N. (2005). "Toplumun Temel Yapı Taşı: Aile”. Ed. S. Güçlü, Kurumlara Sosyolojik Baklş. İstanbul (2005) 27-62.

Akın E. (1991). “Türk Ailesinde Babanın Rolü ve Yeri”. Türk Aile Ansiklopedisi (Cilt 1) 147-155. Ankara 1991.

Aksu Ş. (2011). Yaşam Alanı-Otorite İlişkisi Açısından Devrim. Kocaeli 2011.

Berger P \& Luckmann T. (2008). Gerçekliğin Sosyal İnşasl: Bir Bilgi Sosyolojisi İncelemesi. Çev. V. Saygıl1-Öğütle. İstanbul 2008.

Bourdieu P. (2006). Pratik Nedenler: Eylem Kuramı Üzerine. Çev. H. U. Tanriöver. İstanbul 2006.

Butler J. (2008). "Olumsal Temeller: Feminizm ve 'Postmodernizm' Sorusu”. Çatışan Feminizmler. Çev. F. E. Sezer. İstanbul (2008) 44-67.

Cevizci A. (2011). Felsefe Sözlüğü. İstanbul 2011.

De Certeau M. (2008). Gündelik Hayatın Keşfi. Cilt 1. Çev. L. Arslan-Özcan. Ankara 2008.

Furedi F. (2013). Paranoyak Anne Babalık: Uzmanları Dikkate Almamak Çocuğunuz İçin En İyisi Olabilir. Çev. A. Tüfekçi. İstanbul 2013.

Giddens A. (2005). Sosyal Teorinin Temel Problemleri. Çev. Ü. Tatlıcan. İstanbul 2005.

Gittins D. (2011). Aile Sorgulanlyor!. Çev. T. Erdem. İstanbul 2011.

Glesne C. (2012). Nitel Araştırmaya Giriş. Çev. A. Ersoy \& P. Yalçınoğlu. Ankara 2012.

Goody J. (2004). Avrupa'da Aile: Bir Tarihsel-Antropolojik Deneme. Çev. S. Arısoy. İstanbul 2014.

Hançerlioğlu O. (2007). Toplumbilim Sözlüğ̈̈. İstanbul 2007.

Kağıtçıbaşı Ç. (n.d.). "Kültür ve Ana-Babalık". Eds. M. Sayıl \& B. Yağmurlu, Ana-babalık Kuram ve Araştırma. İstanbul (n.d.) 61-80.

Kardeş E. (2015). "Aşırı-Bireycilik ve Otoritarizm İkileminin Ötesinde Eğitimde Otorite Sorunu". Sosyoloji Dergisi 30/3 (2015/1) 39-52.

Keyif H. (2008). Aile Destek Hizmetlerinin Değerlendirilmesi ve Kalite Standartlarının Geliștirilmesi. Ankara 2008. 
Kılıç Ç. (2010). "Aile Eğitim Programları ve Türkiye'deki Örnekleri”. Abant İzzet Baysal Üniversitesi Dergisi 10/1 (2010) 99-111.

Koçak A. A. (2004). Baba Destek Programı Değerlendirme Raporu. AÇEV. İstanbul 2004.

Kojeve A. (2007). Otorite Kavramı. Çev. M. Erşen. İstanbul 2007.

LaRossa R. (1988). "Fatherhood and Social Change". Family Relations 37/4 (1988) 451-457.

Malkoç G. (1991). Yetişkin Eğitimi Faaliyeti Olarak Aile Eğitimi ve Bir Uygulama. Ankara (1991) 16-24.

MEB: Aile Eğitimi Programları Tarihsel Gelişimi, MEB Hayat Boyu Öğrenme Genel Müdürlüğü. Kaynak:

$<$ http://hbogm.meb.gov.tr/modulerprogramlar/programlar/cocuk_gelisimi_ve_egitimi/7_11_BADEP_ Programi.pdf $>$.

MEB: Aile Ĕgitimleri İstatistik Verileri. Ankara 2016.

Nirun N. (1999). Sistematik Sosyoloji Açısından Aile ve Kültür. Ankara 1999.

Öztan G. G. (2013). Türkiye'de Çocukluğun Politik İnşası. İstanbul 2013.

Öztürk M. Y. (2012). "Ataerki: Bir Kavramın Yeniden İnşası "Eski Ataerki’nden Ataerkil Kapitalizme”. Ĕgitim Bilim Toplum Dergisi 38/10 (2012) 72-115.

Poster M. (1989). Eleştirel Aile Kuramı. Çev. H. Tapınç. İstanbul 1989.

Sancar S. (2011). Erkeklik: Imkansız İktidar: Ailede, Piyasada ve Sokakta Erkekler. İstanbul 2011.

Sayın Ö. (1990). Aile Sosyolojisi- Ailenin Toplumdaki Yeri. İzmir 1990.

Sills D. L. (1968). International Encyclopedia of the Social Sciences. Vol. 1. USA 1968.

Smelser N. \& Baltes P. (2001). International Encyclopedia of the Social \& Behavioral Sciences. Pergamon 2001.

Supiot A. (2014). Homo Juridicus: Hukukun Anropolojik İşlevi Üzerine Bir Deneme. Çev. B. Açımuz. Ankara 2014.

Şen R. B. \& Demirkan S. (2008). “Türkiye'de Aile Eğitimi ve Yerel Yönetimler/Sivil Toplum Örgütler İçin Uygulamalı Bir Model Önerisi”. V. Aile Şurası Aile Destek Hizmetleri (2008).

Thernborn G. (2004). Between Sex and Power: Family in the World, 1900-2000. New York 2004.

Thoma D. (2011). Babalar: Modern bir Kahramanlık Hikâyesi. Çev. F. Doğan. İstanbul 2011.

Türkçe Sözlük (2009). Haz. Ş. H. Akalın. Ankara 2009.

Üstünoğlu Ü. (1991). Aile Eğitiminde Uygulanabilecek Farkl Yaklaşımlar. (1991) 80-90.

Zeybekoğlu Ö (2013). "Günümüzde Erkeklerin Gözünden Babalık ve Aile”. MJH III/2 (2013) 297-328. 